DOI: 10.20472/BMC.2017.005.009

\title{
IOSEB MAMUKELASHVILI
}

JSC Partnership Fund, Georgia

\section{ELENE KHARABADZE}

Ivane Javakhishvili Tbilisi State University, Georgia

\section{FINANCIAL STATEMENT ANALYSIS TO DETERMINE IPO READINESS: EVIDENCE FROM GEORGIAN STATE-OWNED JOINT STOCK COMPANIES}

\begin{abstract}
:
This paper analyzes financial statements of Georgia's two of the largest state-owned joint stock companies (JSC), Georgian Railway and Georgian Oil and Gas Corporation to determine their readiness for Initial Public Offering (IPO). The above-mentioned firms represent $21 \%$ of the country's JSC population by turnover and their IPO success index incorporates liquidity, profitability and capital and asset ratios. Series of tests illustrate that liquidity is one of the biggest determinants of IPO success with a 74\% influence on the index. Liquidity also improves Return on Capital Employed by $53 \%$ and Return on Assets by $47.5 \%$. Furthermore, we conclude that Return on Assets improves firms' chances of successful IPO by $31 \%$. Consistent with our previous research, we believe that protection of minority shareholders' interests is crucial to the development of securities exchange and suggest specific legislative changes to that effect. We also suggest using constant currency financial reporting to eliminate the effects of currency fluctuations in short-term period.
\end{abstract}

\section{Keywords:}

Financial Statement Analysis; Initial Public Offering; State-owned Joint Stock Companies; Constant Currency Financial Reporting; Protection of Minority Shareholders' Interests; Liquidity; Accounting Standards;

JEL Classification: M41, 016, G15 


\section{Introduction}

This research is based on the premise that equity financing is the most reliable source of funding for joint stock companies. Myers and Majluf argued that firms prefer internal sources of funding and prefer debt to equity if external financing is required (Myers \& Majluf, 1984). They further argued that informational asymmetry is one the biggest obstacles for joint stock companies in obtaining equity financing. In our view, in addition to shareholders' reluctance to give up ownership, informational asymmetry is a key deterrent for joint stock companies that want to conduct initial public offerings (IPO).

The main hypothesis of this research is that financial statement analysis is a useful tool to determine IPO readiness of joint stock companies and there are certain ratios that are particularly important to the outcome of the analysis. We have selected Georgia's two of the largest state-owned joint stock companies, which represent $21 \%$ of the country's JSC population by turnover, to test our hypothesis.

In our previous research, we have concluded that equity financing is particularly sensitive to issues related to informational asymmetry (Kharabadze \& Mamukelashvili, 2016). We have examined financial reporting as a mechanism to reduce informational asymmetry between potential investors and firms' management, and argued that implementation and enforcement of accounting standards are essential to the development of securities exchanges throughout the world, with a particular emphasis on Georgia.

In a separate research paper, we have studied the importance of institutions to the implementation of financial reporting standards and found that protection of minority shareholders' interests is essential to both the full implementation of financial reporting standards, as well as to the development of securities exchange (Kharabadze \& Mamukelashvili, 2016). Our findings are consistent with Modigliani's and Perotti's argument in the sense that "when small investors' rights are poorly protected, the ability of firms to raise equity capital is impaired, and as a result, profitable new ventures will be forsaken" (Modigliani \& Perotti, 1997). Therefore, our argument is based on the notion that fully functioning securities exchanges are essential to the sustainable development of joint stock companies.

Georgia's two major joint stock companies, Georgian Railway (GR) and Georgian Oil and Gas Corporation (GOGC) are being considered for IPO by the Georgian Government. GR has unsuccesfully attempted to list $25 \%$ of its shares on the London Stock Exchange (LSE) in 2012. According to Odell and Chazan "Georgia has pulled the planned listing of its state railway monopoly in London in a further setback for the moribund UK market for initial public offerings. The decision to postpone attempts to raise funds by listing a 25 per cent stake in Georgian Railway as global depositary receipts came just a week after setting the price range at $\$ 15.25$ to $\$ 19$, valuing the company at up to $\$ 1$ billion. In a brief 
statement Georgia's government blamed "challenging capital market conditions" for the decision" (Odell \& Chazan, 2012).

GOGC had also been considered for IPO in 2012. The government of Georgia has transferred its shares of GR and GOGC to the state investment company, JSC Partnership Fund, in order to list the minority shares of the above-mentioned joint stock companies on the LSE.

GR, by statute, is Georgia's only railway operator. "It principally provides freight services, transhipping a variety of cargo, including oil, oil products, ores and grains, originating principally in the east from the Caspian Sea and Central Asia to the Black Sea. The company also provides passenger services. It has a vertically integrated business model, owning and operating the tracks, stations, other infrastructure and rolling stock comprising Georgia's entire national railway system, as well as the land adjoining the tracks. GR sets its own tariffs without the need to obtain governmental approval.

GR's mainline rail network, together with that of CJSC Azerbaijan Railway ("Azerbaijan Railway"), forms the Caucasus railway corridor, a key segment of the Transport Corridor Europe Caucasus Asia ("TRACECA") corridor. The Company's mainline rail network is thus a link in the shortest route from the Caspian Sea and Central Asia to the Black Sea and the Mediterranean basin. As a key link in the transportation chain between Europe and Central Asia, GR believes that it is uniquely positioned to capitalise on trade between Europe and the Caspian Region and Central Asia. Three of the company's lines terminate at the Black Sea, at the Georgian port cities of Batumi, Kulevi and Poti. Access to these ports allows easy on-shipment of transit cargo to the Mediterranean basin and Europe.

The Company operates the national railway system through three strategic business units (SBU): the Freight SBU, which provides freight traffic (transportation and handling) and freight car rental services; the Passenger SBU, which primarily transports passengers within Georgia; and the Infrastructure SBU, which operates, maintains and manages GR's principal infrastructure assets. The Infrastructure SBU provides services only to the Freight SBU and the Passenger SBU and does not conduct business with third-party customers.

The Freight SBU accounts for over 90 per cent of the company's total revenue. GR transports both liquid cargoes (crude oil and oil products) and various dry cargoes, with liquid cargoes accounting for 52 per cent of GR's total freight transportation volumes. Transport of crude oil across the company's rail network is an alternative to oil pipelines, and the crude oil transported by GR primarily originates in Kazakhstan and Azerbaijan. Given its strategic location, as producers seek to diversify their transportation options, the Caucasus corridor should capture a relatively stable share of the crude oil transported in the region, which management estimates should be approximately eight to ten per cent of total Kazakhstan and Azerbaijan production" (Georgian Railway JSC, 2012). 
On the other hand, GOGC's "core activities consist of gas supply, pipeline rental, electricity generation and oil transportation. The company is the sole national oil company in Georgia and is responsible for ensuring the country's gas supply, which it does through the management of its pipeline network. GOGC does not act as the operator of any pipeline.

GOGC also participates in certain upstream activities (including the sale of crude oil received under production sharing agreements). The company was incorporated as a limited liability company on 6 April 2006. The ultimate purpose of the establishment of GOGC was the consolidation of energy sector assets in Georgia under one integrated management, with the view of creating a national oil and gas company.

On 5 September 2011, the Company changed its corporate form from a limited liability company, re-registering as a joint stock company under the Law on Entrepreneurs of Georgia. In conducting its gas supply activities, GOGC purchases from Georgian Gas Transportation Company (a related party) natural gas transported through the Main Gas Pipeline System, which Georgian Gas Transportation Company, as the state-owned operator of the Main Gas Pipeline System, receives as an in-kind transit fee for transporting Russian natural gas to Armenia. The Main Gas Pipeline System is $100 \%$ owned by GOGC.

GOGC also purchases natural gas, which has been transported through the Georgian section of the South Caucasus Pipeline, pursuant to two long-term contracts concluded with South Caucasus Pipeline Option Co. and Azerbaijan Gas Supply Company. The Company sells all natural gas it purchases from South Caucasus Pipeline Option Co., Azerbaijan Gas Supply Company and Georgian Gas Transportation Company to SOCAR Gas Export-Import pursuant to the SOCAR Gas Sales Agreement.

In addition, pursuant to the terms of the SOCAR Sales and Purchase Agreement, the Company purchases natural gas from SOCAR for on-sale to satisfy general consumption and power generation needs in Georgia, in accordance with the SOCAR Gas Sales Agreement" (Georgian Oil and Gas Corporation JSC, 2016).

Although success of IPOs depends on various external characteristics, the importance of financial statement analysis to predict the IPO success cannot be underestimated. The IPO success model should incoprorate various financial statement ratios and archival research techniques should be utilized to detrmine the IPO success chances within a specified time period.

\section{Related Works and Methodology}

Mohanram developed the financial statement analysis index "based on a combination of traditional fundamentals such as earnings and cash flows and measures appropriate for growth firms such as the stability of earnings and growth and the intensity of R\&D, capital expenditure and advertising" (Mohanram, 2005). One of the coefficients that he relied in 
his financial statement analysis was Return on Assets (ROA) to determine how efficiently firms use assets to generate portability. We have also determined that ROA should be incorporated in the IPO success index.

Liquidity is also one of the key financial metrics that investors and financial analysts examine in evaluating a joint stock company performance. Altman argues that "academics seem to be moving toward the elimination of ratio analysis as an analytical technique in assessing the performance of the business enterprise. Theorists downgrade arbitrary rules of thumb, such as company ratio comparisons, widely used by practitioners" (Altman, 1968). He also argues that ratios measuring profitability and liquidity are the most relevant indicators of firms' financial condition.

Capital structure ratios are also essential in financial statement analysis of joint stock companies. Xiaoyue and Xiaodong have concluded that "equity structure and corporate governance are closely related to firm performance" (Xiaoyue \& Xiaodong, 2001). We have determined that examining ratios such as Equity/Debt ratio and Return on capital employed (ROCE) (calculated as Earnings before interest and tax (EBIT) divided by Capital employed, which is calculated as the sum of equity and long-term liabilities) are essential to assess the success of potential IPOs.

IPO success index should incorporate the following elements:

$$
S=P_{c}+P_{o}+(0.2) * L_{c}+(0.2) * L_{a}+C+R O A+R O C E+(0.2) * A_{a}
$$

$\boldsymbol{P}_{\boldsymbol{c}}-$ net cash flow provided by operating activities divided by gross cash flow provided by operating activities;

$\boldsymbol{P}_{\boldsymbol{o}}-$ operating income margin (operating income divided by revenue);

$L_{c}-\quad$ current ratio (current assets divided by current liabilities);

$L_{a}-$ overall liquidity ratio (total assets divided by total liabilities);

C - capital structure ratio (equity divided by total liabilities);

$\boldsymbol{R O A}$ - return on assets (net income divided by total assets);

ROCE - return on capital employed (Earnings before interest and tax (EBIT) divided by Capital employed, which is calculated as the sum of equity and long-term liabilities);

$\boldsymbol{A}_{\boldsymbol{a}}-$ active (depreciable) share of fixed assets.

The formula above is derived from the assumption that profitability, liquidity, capital structure and asset ratios are essential to determine the IPO prospects of a joint stock company. Table 1 illustrates Georgian Railway's general profitability trends by comparing Revenue, Operating Income and Net Income from 2012 to 2015. 
Table 1: Profitability Trends of Georgian Railway

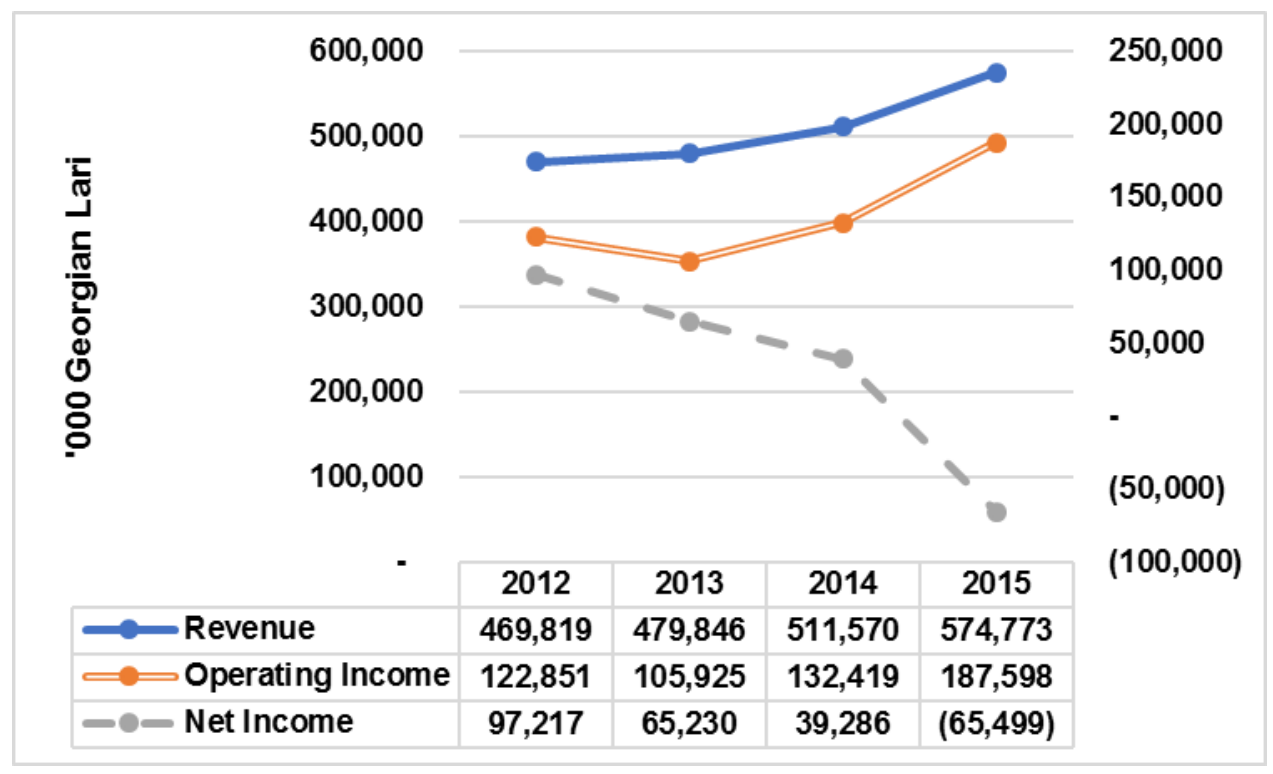

Source: Georgian Railway's audited financial statements

According to Table 1, Georgian Railway's Revenue increased each year from 2012 to 2015: in 2015, Revenue increased by $12 \%$ and totaled 574.8 million Georgian Lari (GEL). Operating Income also increased in 2015 by $42 \%$ and totaled 187.6 million GEL, while Net Income decreased 2.7 times and GR incurred Net Loss in the amount of 65.5 million GEL.

The paradoxical tendency of incurring Net Loss in 2015, while experiencing growth in both Revenue and Operating Income can be explained by Georgian Railway's foreigncurrency denominated long-term liabilities. More specifically, GR has issued unsecured bonds in the amount of 500 million United Stated Dollars (USD) on London Stock Exchange and according to International Accounting Standard (IAS) 21, the company has to revalue its foreign-currency denominated liabilities for each reporting period and reflect differences in its income statement. From 31 December 2014 to 31 December 2015, GEL has lost $29 \%$ of its value with respect to USD, which resulted in the loss of 226.8 million GEL on GR's income statement. If we "normalize" Georgian Railway's Net Income by adding back firm's foreign exchange loss, the company has Net Income of 161.3 million GEL in 2015.

Table 2 illustrates the similar tendency for Georgian Oil and Gas Corporation as it is for Georgian Railway. In 2015, GOGC's Revenue increased by $38 \%$ and totaled 495.4 million GEL, which is the highest figure from 2012 to 2015. Operating Income also increased by $5 \%$ in 2015 and totaled 96.6 million GEL, whereas Net Income decreased by $57 \%$ and totaled 36.2 million GEL, which is the lowest figure in years 2012-2015. Therefore, on one hand GOGC experienced increases in both Revenue and Operating Income and on the other hand, Net Income was reduced substantially. 
Table 2: Profitability Trends of Georgian Oil and Gas Corporation

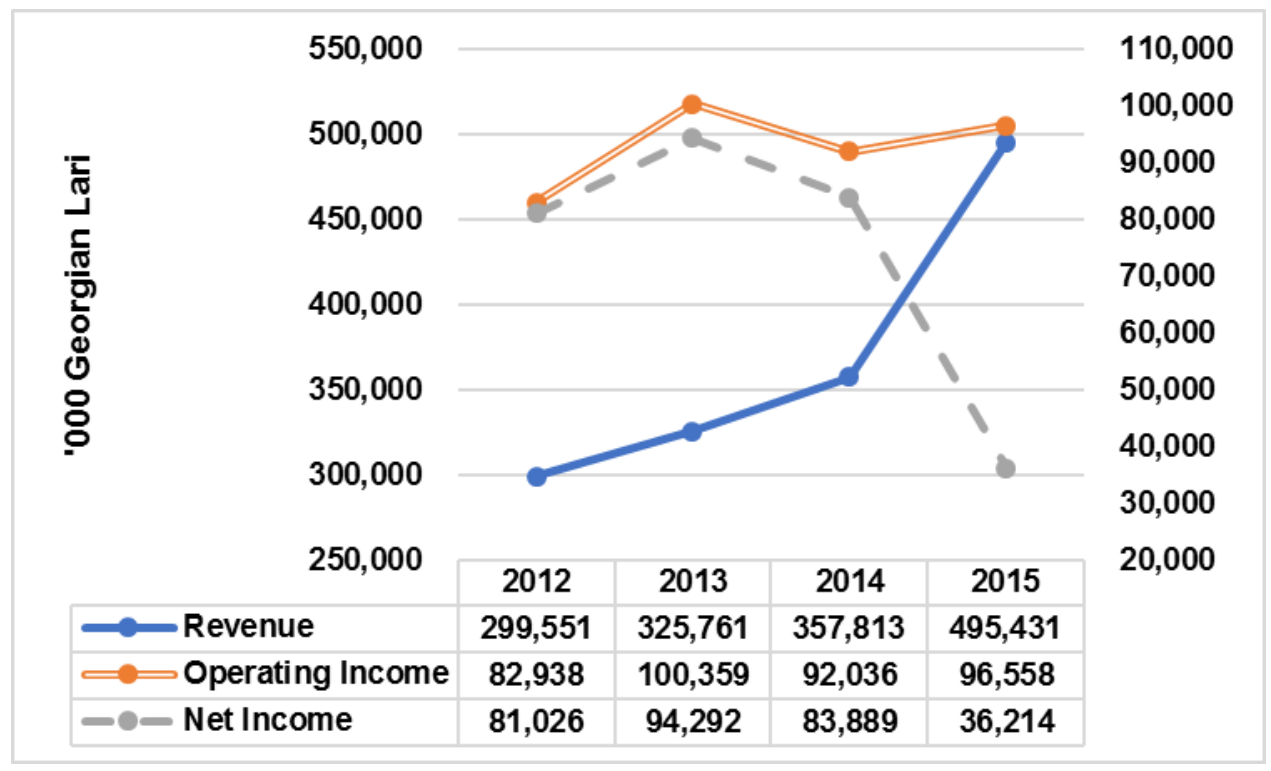

Source: Georgian Oil and Gas Corporation's audited financial statements

Georgian Oil and Gas Corporation has similar explation for the paradoxical profitability trend as does Georgian Railway. More specially, GOGC has issued unsecured bonds in the amount of 250 million USD on the London Stock Exchange and the foreign currency revaluation of the bonds resulted in 65.1 million GEL accounting loss in 2015. Unlike GR, GOGC did not experience net loss because GR's bonds demoninated in foreign currency were twice as much as GOGC's bonds.

Table 3: Liquidity Ratios of Georgian Railway and Georgian Oil and Gas Corporation

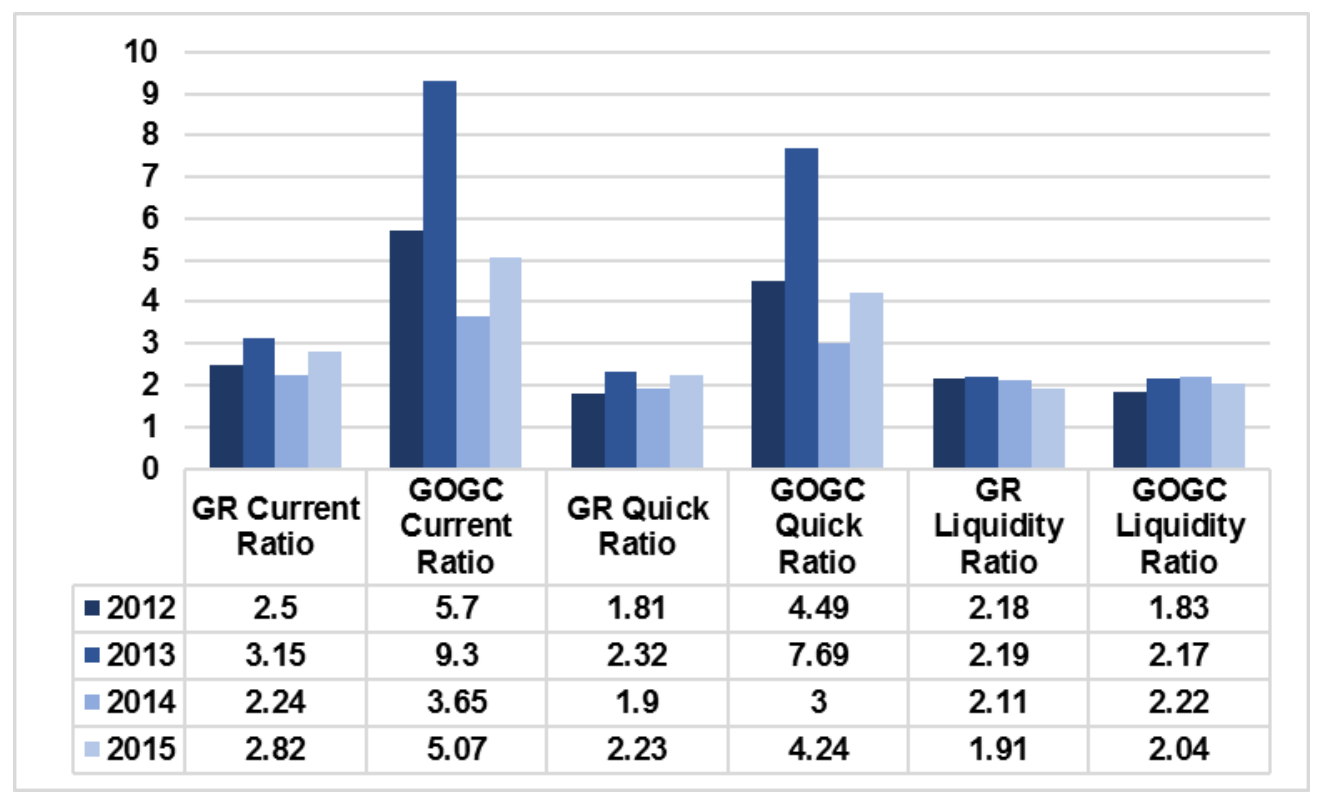

Source: GR's and GOGC's audited financial statements 
Notably, if the Georgian Stock Exchange were not dormant and underdeveloped, Georgia's above-mentioned state-owned joint stock companies could have avoided 291 million GEL loss in 2015. Therefore, the development of the country's security exchange is essential to sustainability of state-owned strategic joint stock companies (The World Bank, 2015).

In order to analyze liquidity, Table 3 lists basic liquidity ratios of Georgian Railway and Georgian Oil and Gas Corporation. In general, liquidity ratios are considered to be positive if they exceed 1. Both GR's and GOGC's Current Ratio exceed 2 from 2012 to 2015. In 2013, GOGC's Current Ratio was as high as 9.3. GR's Current Ratio exceeded 3 in 2013. GR's average Current Ratio in years 2012-2015 was 2.7, whereas GOGC average current ratio in years 2012-2015 was 5.9.

In terms of Quick Ratio, GR averaged 2 in years 2012-2015, whereas GOGC averaged 4.9 during the same period. Futhermore, both GR and GOGC averaged 2 in Liqudity Ratio from 2012 and 2015. Therefore, it is woth mentioning that both of the joint stock companies described above are fairly liquid, although Georgian Oil and Gas Corporation has better liquidity ratios than Georgian Railway.

Table 4: IPO success index for Georgian state-owned strategic joint stock companies

\begin{tabular}{|l|r|r|r|r|r|r|r|r|}
\hline \multirow{2}{*}{ Ratio } & \multicolumn{4}{|c|}{ Georgian Railway } & \multicolumn{3}{c|}{ Georgian Oil and Gas Corporation } \\
\cline { 2 - 10 } & \multicolumn{1}{|c|}{$\mathbf{2 0 1 2}$} & \multicolumn{1}{|c|}{$\mathbf{2 0 1 3}$} & $\mathbf{2 0 1 4}$ & \multicolumn{1}{c|}{$\mathbf{2 0 1 5}$} & \multicolumn{1}{c|}{$\mathbf{2 0 1 2}$} & \multicolumn{1}{c|}{$\mathbf{2 0 1 3}$} & $\mathbf{2 0 1 4}$ & \multicolumn{1}{c|}{$\mathbf{2 0 1 5}$} \\
\hline $\boldsymbol{P}_{\boldsymbol{c}}$ & 0.49 & 0.45 & 0.53 & 0.53 & 0.25 & 0.41 & 0.21 & 0.04 \\
\hline $\boldsymbol{P}_{\boldsymbol{o}}$ & 0.26 & 0.22 & 0.26 & 0.33 & 0.28 & 0.31 & 0.26 & 0.19 \\
\hline $\boldsymbol{L}_{\boldsymbol{c}}$ & 0.5 & 0.63 & 0.45 & 0.56 & 1.14 & 1.86 & 0.73 & 1.01 \\
\hline $\boldsymbol{L}_{\boldsymbol{a}}$ & 0.44 & 0.44 & 0.42 & 0.38 & 0.37 & 0.43 & 0.44 & 0.41 \\
\hline $\boldsymbol{C}$ & 1.18 & 1.19 & 1.11 & 0.91 & 0.83 & 1.17 & 1.22 & 1.04 \\
\hline $\boldsymbol{R O A}$ & 0.03 & 0.02 & 0.01 & -0.02 & 0.09 & 0.09 & 0.07 & 0.03 \\
\hline $\boldsymbol{R O C E}$ & 0.04 & 0.04 & 0.05 & 0.06 & 0.1 & 0.1 & 0.09 & 0.07 \\
\hline $\boldsymbol{A}_{\boldsymbol{a}}$ & 0.17 & 0.15 & 0.15 & 0.14 & 0.16 & 0.19 & 0.1 & 0.19 \\
\hline $\boldsymbol{S}$ & $\mathbf{3 . 1 1}$ & $\mathbf{3 . 1 3}$ & $\mathbf{2 . 9 8}$ & $\mathbf{2 . 9}$ & $\mathbf{3 . 2 2}$ & $\mathbf{4 . 5 6}$ & $\mathbf{3 . 1 3}$ & $\mathbf{2 . 9 8}$ \\
\hline
\end{tabular}

Table 4 list the computation of IPO success index for Georgian Railway and Georgian Oil and Gas Corporation. In 2012, Georgian Railway's IPO success index was 3.11, in 2013 - 3.13, in $2014-2.98$ and in 2015 - 2.9. Georgian Oil and Gas Corporation's IPO success index in 2012 amounted to 3.22, in $2013-4.56$, in $2014-3.13$ and in $2015-$ 2.98. Both joint stock companies have the highest index in 2013, which according to the model below give them the best chance to start IPO procedures. However, GR's IPO success index in 2013 is only 1\% higher than it was in 2012 when the IPO attempt failed. Therefore, we have determined that IPO success index close to or below 3 is considered to be a negative indicator for joint stock companies. 
Table 5: Correlation matrix for IPO success index financial ratios

\begin{tabular}{|c|c|c|c|c|c|c|c|c|c|c|}
\hline & & $\boldsymbol{P}_{c}$ & $P_{0}$ & $L_{c}$ & $L_{a}$ & $C$ & $R O A$ & ROCE & $A_{a}$ & $S$ \\
\hline \multirow[t]{3}{*}{ Pc } & $\begin{array}{l}\text { Pearson } \\
\text { Correlation }\end{array}$ & 1 & .550 & -.336 & .113 & .128 & -.459 & -.521 & -.101 & .058 \\
\hline & Sig. (2-tailed) & & .158 & .416 & .790 & .763 & .252 & .185 & .812 & .892 \\
\hline & $\mathrm{N}$ & 8 & 8 & 8 & 8 & 8 & 8 & 8 & 8 & 8 \\
\hline \multirow[t]{3}{*}{ Po } & $\begin{array}{l}\text { Pearson } \\
\text { Correlation }\end{array}$ & .550 & 1 & .224 & -.376 & -.311 & .064 & .331 & -.161 & .377 \\
\hline & Sig. (2-tailed) & .158 & & .594 & .359 & .454 & .880 & .424 & .703 & .357 \\
\hline & $\mathrm{N}$ & 8 & 8 & 8 & 8 & 8 & 8 & 8 & 8 & 8 \\
\hline \multirow[t]{3}{*}{ Lc } & $\begin{array}{l}\text { Pearson } \\
\text { Correlation }\end{array}$ & .336 & .224 & 1 & -.086 & -.057 & $.742^{*}$ & $.774^{*}$ & .529 & $.882^{* *}$ \\
\hline & Sig. (2-tailed) & .416 & .594 & & .839 & .894 & .035 & .024 & .178 & .004 \\
\hline & $\mathrm{N}$ & 8 & 8 & 8 & 8 & 8 & 8 & 8 & 8 & 8 \\
\hline \multirow[t]{3}{*}{ La } & $\begin{array}{l}\text { Pearson } \\
\text { Correlation }\end{array}$ & .113 & -.376 & -.086 & 1 & $.993^{* *}$ & .065 & -.333 & -.090 & .227 \\
\hline & Sig. (2-tailed) & .790 & .359 & .839 & & .000 & .879 & .420 & .832 & .589 \\
\hline & $\mathrm{N}$ & 8 & 8 & 8 & 8 & 8 & 8 & 8 & 8 & 8 \\
\hline \multirow[t]{3}{*}{ C } & $\begin{array}{l}\text { Pearson } \\
\text { Correlation }\end{array}$ & .128 & -.311 & -.057 & $.993^{* *}$ & 1 & .068 & -.283 & -.132 & .266 \\
\hline & Sig. (2-tailed) & .763 & .454 & .894 & .000 & & .873 & .497 & .756 & .525 \\
\hline & $\mathrm{N}$ & 8 & 8 & 8 & 8 & 8 & 8 & 8 & 8 & 8 \\
\hline \multirow[t]{3}{*}{ ROA } & $\begin{array}{l}\text { Pearson } \\
\text { Correlation }\end{array}$ & .459 & .064 & $.742^{*}$ & .065 & .068 & 1 & $.811^{*}$ & .123 & 642 \\
\hline & Sig. (2-tailed) & .252 & .880 & .035 & .879 & .873 & & .015 & .771 & .086 \\
\hline & $\mathrm{N}$ & 8 & 8 & 8 & 8 & 8 & 8 & 8 & 8 & 8 \\
\hline \multirow[t]{3}{*}{ ROCE } & $\begin{array}{l}\text { Pearson } \\
\text { Correlation }\end{array}$ & $\begin{array}{r}- \\
.521\end{array}$ & 331 & $.774^{*}$ & -.333 & -.283 & $.811^{*}$ & 1 & .012 & .552 \\
\hline & Sig. (2-tailed) & .185 & .424 & .024 & .420 & .497 & .015 & & .977 & .156 \\
\hline & $\mathrm{N}$ & 8 & 8 & 8 & 8 & 8 & 8 & 8 & 8 & 8 \\
\hline \multirow[t]{3}{*}{$\mathbf{A a}$} & $\begin{array}{l}\text { Pearson } \\
\text { Correlation }\end{array}$ & $.101^{-}$ & -.161 & .529 & -.090 & -.132 & .123 & .012 & 1 & .434 \\
\hline & Sig. (2-tailed) & .812 & .703 & .178 & .832 & .756 & .771 & .977 & & .282 \\
\hline & $\mathrm{N}$ & 8 & 8 & 8 & 8 & 8 & 8 & 8 & 8 & 8 \\
\hline \multirow[t]{3}{*}{$\mathbf{S}$} & $\begin{array}{l}\text { Pearson } \\
\text { Correlation }\end{array}$ & .058 & . 377. & $.882^{* *}$ & .227 & .266 & .642 & .552 & .434 & 1 \\
\hline & Sig. (2-tailed) & .892 & .357 & .004 & .589 & .525 & .086 & .156 & .282 & \\
\hline & $\mathrm{N}$ & 8 & 8 & 8 & 8 & 8 & 8 & 8 & 8 & 8 \\
\hline
\end{tabular}

Our prediction is that IPO success index of more than 5 is considered to be a positive indicator for Georgian strategic joint stock companies. However, this hypothesis needs to be tested in later years to determine the validity of this theory. Notably, both joint stock companies, which have drastically different business models, have the highest IPO success index in 2013 and the lowest in 2015, which to a certain index validates our approach to ratio analysis regarding IPOs.

Table 5 illustrates the correlation matrix for IPO success index ratios for both Gorgian Railway and Georgian Oil and Gas Corporation. IBM SPSS was used to derive the correlation matrix based on 2012-2015 financial ratio data indicated in Table 4. 
According to Table 5, there are several statistically significant relationships between ratios and IPO success index. For instance, there is $88 \%$ correlation between the Current Ratio and IPO success index ( $p=0.004)$. This confirms financial analysts' motto of "cash is king" in the sense that the firms' ability to meet their obligations is highly correlated with firms' IPO success.

Although not statistically significant, Return on Assets is very close to being significantly correlated to IPO success index by $64 \%$ indicator. To a certain extent, this confirms Mohanram's assertion in the sense that Return on Assets is a very important ratio to consider during financial statement analysis of IPOs.

It is important to note that Current Ratio is also statistically significantly related to Return on Assets and Return on Capital Employed with coefficients of $74 \%$ and $77 \%$, respectively. This suggests that liquidity also improves the efficiency with which capital is employed in Georgian state-owned joint stock companies.

To examine cause-and-effect relationship between the Current Ratio and IPO success index, we have conducted regression analysis using the IBM SPSS software, in which the Current Ratio was selected as an independent variable and the IPO success index - as dependent variable. The test resulted in the coefficient with the value of 0.741 (refer to Table 5), which suggests that short-term liquidity is a $74 \%$ precondition to a successful IPO.

Table 5: IPO success index regression analysis - Current Ratio as independent variable

Model Summary

\begin{tabular}{|l|r|r|r|r|}
\hline Model & $\mathrm{R}$ & R Square & $\begin{array}{c}\text { Adjusted R } \\
\text { Square }\end{array}$ & $\begin{array}{c}\text { Std. Error of } \\
\text { the Estimate }\end{array}$ \\
\hline 1 & $.882^{\mathrm{a}}$ & .778 & .741 & .27422 \\
\hline
\end{tabular}

a. Predictors: (Constant), Current Ratio

It is important to note that the regression analysis above is statistically significant $(p=0.004)$ because according to Table 6 , significance coefficient is less than 0.05 .

Table 6: Statistical significance of IPO success index regression analysis - Current Ratio as independent variable

ANOVA $^{\mathrm{a}}$

\begin{tabular}{|c|c|c|c|c|c|}
\hline Model & $\begin{array}{c}\text { Sum of } \\
\text { Squares }\end{array}$ & df & $\begin{array}{c}\text { Mean } \\
\text { Square }\end{array}$ & $\mathrm{F}$ & Sig. \\
\hline $\begin{array}{ll}1 & \text { Regression }\end{array}$ & 1.582 & $\overline{1}$ & 1.582 & 21.044 & $.004^{b}$ \\
\hline Residual & .451 & 6 & .075 & & \\
\hline Total & 2.034 & 7 & & & \\
\hline
\end{tabular}

a. Dependent Variable: IPO success index

b. Predictors: (Constant), Current Ratio 
We have further conducted regression analysis where the Return on Assets ratio is an independent variable and IPO success index a dependent variable. The analysis resulted in the regression coefficient of 0.314 , which implies that Return on Assets is a $31 \%$ precondition to a successful IPO. Similarly to the results of correlation analysis, the regression analysis mentioned above is close to being statistically significant because $p$ value equals 0.086 (which is not less than 0.05 ).

The importance of the Current Ratio to the IPO success index is further demonstrated by the fact that the regression analyses where the Current Ratio was an independent variable and the Return of Assets and the Return on Capital Employed were dependent variables resulted in regression coefficients of 0.475 and 0.532 , respectively. In both case, the regression analyses were statistically significant with $p$ values of 0.035 and 0.024 , respectively.

\section{Conclusion}

According to Section 54 of the Law on Entrepreneurship of Georgia, majority shareholders of joint stock companies who own more than $95 \%$ of shares have the right to force minority shareholders sell their shares at fair value (The Parliament of Georgia, 2016). In our judgment, the Section 54 mentioned above conflicts with the Article 21 of the Constitution of Georgia, which states that the restriction on property rights shall be permissible for the purpose of pressing social needs (The Parliament of Georgia, 2013). Therefore, majority shareholders' willingness to buy the minority shareholders' share of ownership can be considered a pressing social need in very rare circumstances. In our previous research, we have demonstrated that proection of minority shareholers' interests is the most important precondition to the development of securities exchange, and we recommend removing the Section 54 from the Law on Entrepreneurship of Georgia, which will serve as the catalyst for the development of the dormant Georgian Stock Exchange.

We have used ratio analyses to derive the IPO success index based on profitability, liquidity and asset and capital structure ratios. Both Georgian Railway and Georgian Oil and Gas Corporation have the highest IPO success index in 2013 and lowest in 2015. Based on the financial statement analyses of GR and GOGC from 2012 to 2015, we have determined that IPO success index close to or below 3 is undesirable and the IPO success index above 5 is desirable for joint stock companies.

The correlation analyses demonstrated that there is $88 \%$ correlation between the Current Ratio and IPO success index and 64\% correlation between Return of Assets and IPO success index. Therefore, we have determined that Current Ratio and Return on Assets are the most important ratios in predicting IPO success of Georgian state-owned joint stock companies.

The importance of Current Ratio is multi-faceted in the sense that there is a $74 \%$ correlation between Current Ratio and Return on Assets and 77\% correlation between 
Current Ratio and Return on Capital Employed. Table 7 illustrates the results of regression analyses where Current Ratio was an independent variable and IPO success index, Return on Assets and Return on Capital Employed were dependent variables.

Based on the results of regression analyses, high Current Ratio is a $74 \%$ precondition to a successful IPO. Furthermore, high Current Ratio is $53 \%$ precondition to having a high Return on Capital Employed ratio, which in turn is important in the IPO process. High Current Ratio is also deemed as a $47.5 \%$ precondition to having a high Return on Assets ratio.

Table 7: Regression analysis of Current Ratio as an independent variable

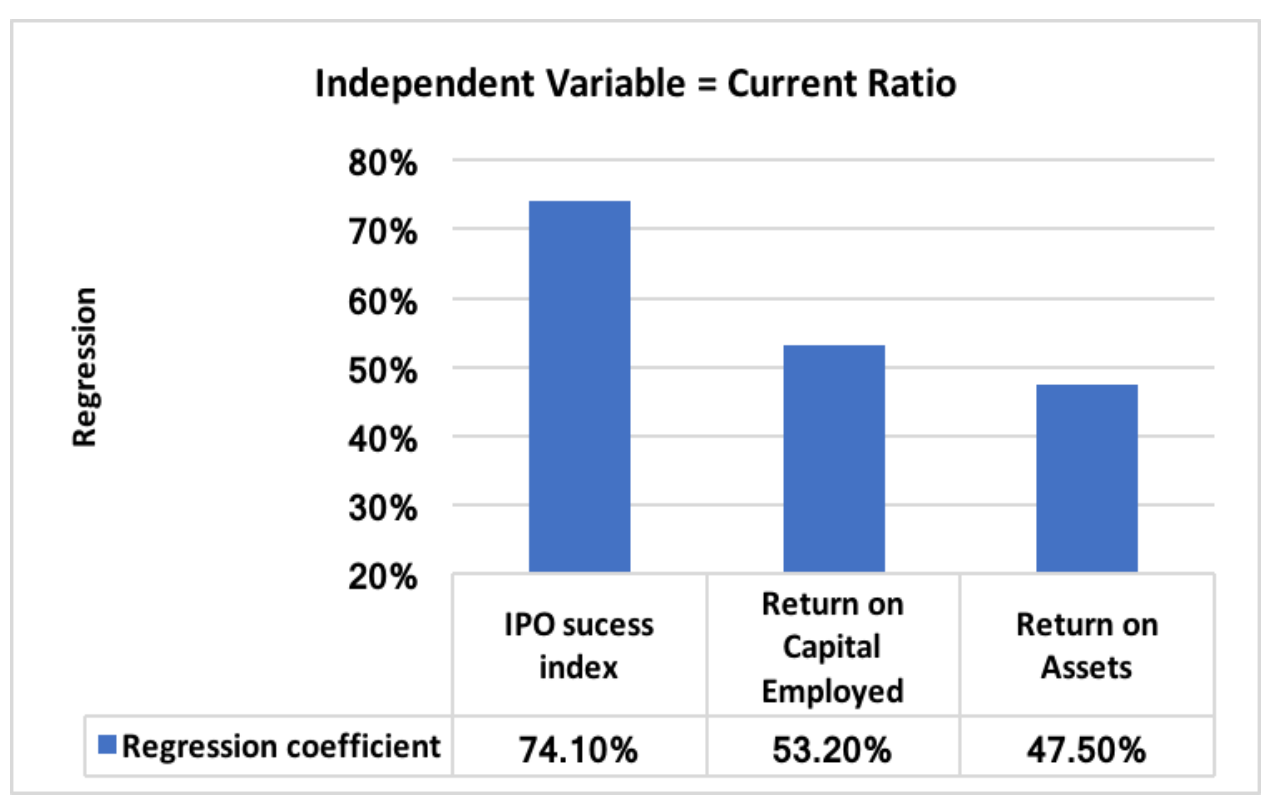

The regression analysis where the Return on Assets was independent variable and IPO success index was a dependent variable resulted in $31 \%$ coefficient. This result was very close to being statistically significant because $p$ value was 0.086 , which is close to 0.05 .

Our recommendation to management of Georgian Railway and Georgian Oil and Gas Corporation is to use constant currency financial reporting. According to International Accounting Standard (IAS) 21 "The Effect of Changes in Foreign Exchange Rates", foreign currency denominated liabilities, which in case of GR and GOGC were 750 million USD, have to be revalued at each financial reporting date and effects of such changes have to be reflected on income statement, which in case of GR and GOGC were 291 million GEL in 2015.

Using constant currency financial reporting can eliminate the effects of exchange rate fluctuations when calculating financial performance figures (Saudagaran \& Diga, 1997). Constant currency financial statements can be presented in the management discussion and analysis or general business overview sections of the financial statements and is great way to present information to potential investors without the effects of short-term currency fluctuations that can be misleading. 
The International Financial Reporting Standards (IFRS) do not prohibit the use of constant currency financial reporting. Such a reporting practice is considered to be a nonIFRS measure and International Accounting Standard Board has numerously stated that non-IFRS measures can significantly enhance financial reporting (Hoogervorst, 2016).

\section{References}

Altman, E. I. (1968). Financial ratios, discriminant analysis and the prediction of corporate bankruptcy. The Journal of Finance.

Gao, W., \& Zhu, F. (2013). Information asymmetry and capital structure around the world. Pacific-Basin Finance Journal, 1-42.

Georgian Oil and Gas Corporation JSC. (2016). Prospectus. Retrieved from https://www.rnspdf.londonstockexchange.com/rns/4001W_-2016-426.pdf?_ga=1.264662223.1988231722.1487250769

Georgian Railway JSC. (2012). Propestus. Retrieved from http://www.railway.ge/files/gr\%20final\%20.pdf

Hail, L., \& Leuz, C. (2006). International Differences in the Cost of Equity Capital: Do Legal Institutions and Securities Regulation Matter? Journal of Accounting Research, 1-44.

Hoogervorst, H. (2016). Performance reporting and the pitfalls of non-GAAP metrics. IASB Speech.

International Accounting Standards Board. (2005). International Accounting Standard 21 - The Effects of Changes in Foreign Exchange Rates.

Kharabadze, E., \& Mamukelashvili, I. (2016). Impact of Financial Reporting on Access to Capital. Journal of Business and Economics.

Kharabadze, E., \& Mamukelashvili, I. (2016). The Development of Financial Reporting and Auditing Standards throughout the World: Importance of Institutions. Journal of Business \& Management.

Kim, J.B., Shi, H., \& Zhou, J. (2014). International Financial Reporting Standards, institutional infrastructures, and implied cost of equity capital around the world. Review of Quantitative Finance \& Accounting, 469-507.

Lantto, A., \& Sahlström, P. (2009). Impact of International Financial Reporting Standard adoption on key financial ratios. Accounting and Finance, 341-361.

Manyara, M., \& Benuto, L. (2014). Adoption of International Financial Reporting Standards Improves Access to Equity Capital in Australia. Academy of Accounting and Financial Studies Journal.

Modigliani, F., \& Perotti, E. (1997). Protection of Minority Interest and the Development of Security Markets. Managerial and Decision Economics, 519-528.

Mohanram, P. S. (2005). Separating Winners from Losers among Low Book-to-Market Stocks using Financial Statement Analysis. Review of Accounting Studies.

Myers, S. C., \& Majluf, N. S. (1984). Corporate Financing and Investment Decisions When Firms Have Information that Investors Do Not Have. Journal of Financial Economics, 187-221. 
Naranjo, P., Saavedra, D., \& Verdi, S. (2014). Financial Reporting Regulation and Financing Decisions. Working Paper, 1-56.

Odell, M., \& Chazan, G. (2012). Georgian Railway pulls London IPO. Financial Times.

Oswald, S., \& Jahera, J. (1991). The influence of ownership on performance: An empirical study. Strategic Management Journal, 321-326.

Revsine, L., Collins, D., \& Johnson, B. W. (2005). Financial Reporting and Analysis. Prentice Hall.

Saudagaran, S. M., \& Diga, J. G. (1997). Financial reporting in emerging capital markets: Characteristics and policy issues. Accounting Horizons.

Schwab, K. (2015). The Global Competitiveness Report 2014-2015. World Economic Forum, 1-565.

The Parliament of Georgia. (2013). The Constitution of Georgia.

The Parliament of Georgia. (2016). The Law on Entrepreneurship.

The World Bank. (2015). Reports on the Observance of Standards and Codes (ROSC): Update on Georgia. Retrieved from http://documents.worldbank.org/curated/en/254551468189259272/pdf/ACS13210REVISED-Georgia-ROSC-AA-Report-FINAL-092015-Box393232B-PUBLIC-ENGLISHDissemination.pdf

Xiaoyue, C., \& Xiaodong, X. (2001). Equity Structure,Firm Performance and the Protection for Investers' Interest. Economic Research Journal. 